\title{
Relationship of Sleep Satisfaction and the Academic Performance of Grade 12 Students of Talangan Integrated National High School
}

\author{
Felyrose B. Ortillano, Elymar A. Pascual \\ ofelyrose@gmail.com \\ Department of Education, Nagcarlan, Laguna, Philippines, 4002
}

\begin{abstract}
This study focused on determining the relationship of sleep satisfaction and the academic performance of Grade 12 students in Talangan Integrated National High School, Nagcarlan, Laguna, S.Y. 2021-2022. The main reason why the researcher conducted this study is that many students nowadays do not perform well at school and she observed that maybe sleep deprivation is one of the reasons why. The quantitative method of research was followed. The respondents of this study were selected using the Slovin's formula. The strands available in Grade 12 are GAS/ABM, ICT, CAREGIVING and AUTOMOTIVE. They answered a survey questionnaire to know how their sleep is related to their performance in school. The relationship was found to be significant using Pearson $r$ proven by $p$ value $0.00($ alpha 0.05$)$. From the survey, the researcher came up with the conclusion; there is a significant relationship between the sleep satisfaction and the academic performance of a student. Thus, obtaining good sleep at night results in significantly good academic performance at school.
\end{abstract}

Keywords: sleep, student, performance

\section{Introduction}

Sleep plays a vital role in contrast with the performance of a student at home and also at school because it helps them to be more engaged and active in the activities in the next day especially when they achieve enough sleep. Students around the world need to have enough sleep although most of them are having hard time to achieve the right sleep hours.

Students nowadays are totally engaged with gadgets like cell phones and computers. They prefer to face their gadgets at night than to sleep early for so many reasons; late night talks with their boyfriends or girlfriends, playing games, reading Wattpad etc. Since they are classified as $21^{\text {st }}$ Century Learners, they are more "techy" that they didn't realize that they've used it too much. That's the main and the most common reason why students stay up late at night. Also another thing, some of them are busy doing their assignments and projects that sometimes reach very late at night. But whatever the reason for having a lack of sleep at night is, it has a corresponding consequence; to the health of the student and to their performance especially in school.

There are so many cases in schools about having inadequate sleep that the performance of the students was totally affected. How do sleep satisfaction of a student of Talangan Integrated National High School affect their performance at school? What are the things to do to have adequate sleep at night to have a good performance in school? These are just some issues that this paper contains.

\subsection{Background of the Study}

Talangan Integrated National High School has been established since 1970. Before, it was not integrated until 2016 the school implemented the integration of senior high school instead of just junior high school. Many changes happen to improve the facilities of the school. Classes are shifting because there is an ongoing construction of new building for additional classrooms since students are continuously increasing 

shifts. STEP sections of grades seven to 10 are the only whole day classes. Three of the classes are staying in the school's covered court.

Teenagers need at least nine and a half hours of sleep every night and if they did not achieve enough of it, there would be a big possibility of losing attentiveness during the next day according to the National Sleep Foundation.

Most of the students were not active during class. Some of them were sleeping during class hours if not; they are not attentive in their class. The researcher observed that those students or the researcher herself were feeling drowsy at school because they are tired of night-long wakefulness because of projects and assignments or sometimes just because of playing games and reading Wattpad which are the most common reason for the millennial today. The purpose of this study is to show the relationship of sleep satisfaction to the students of Talangan Integrated National High School. Also, to show the things students may do to maintain attentiveness in school during class hours.

\subsection{Theoretical Framework}

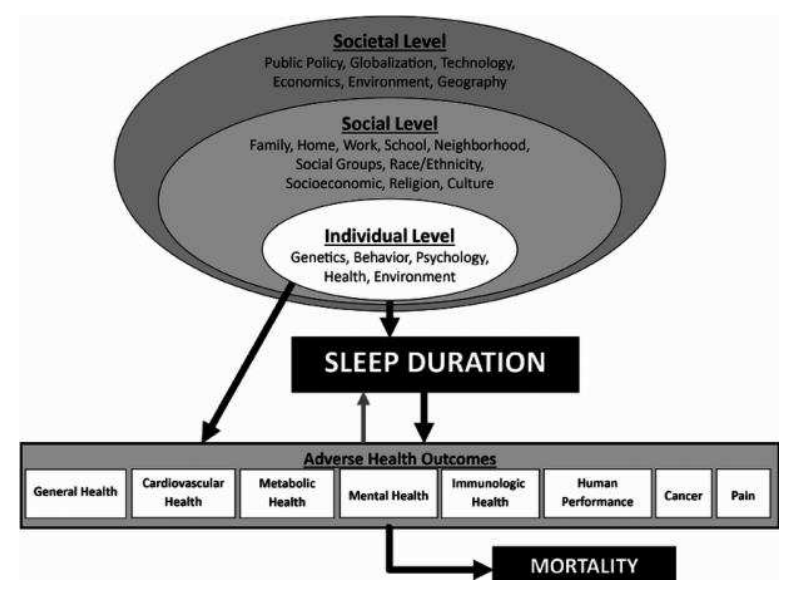

Figure 1. Biopsychosocial model of sleep duration drivers

According to Grandner, Hale, Moore \& Patel (2010), sleep is an important biological imperative. Genetic and psychologic factors helps in meeting the body's need for sleep duration, timing, regularity and quality. But most of the factors that affects the inter-individual variability in sleep are environmental, behavioral, psychological, cultural and social factors.

Sleep duration associates to the level of variability of a person either individual, social, and societal level. It merely affects the health and performance of a person depending on how they achieve sleep.

Students' performance in school was seriously affected by how they sleep at night. It is very common to students that if they don't get enough sleep at night, it surely affects their performance in school. Most of them were so sleepy at school because of long wakefulness at night instead of getting enough sleep. In this study, this is helpful for the researcher to identify if there is a relationship between the sleep satisfaction and the academic performance of a student.

\subsection{Conceptual Framework}

The figure on the next page shows the conceptual framework for this study. 

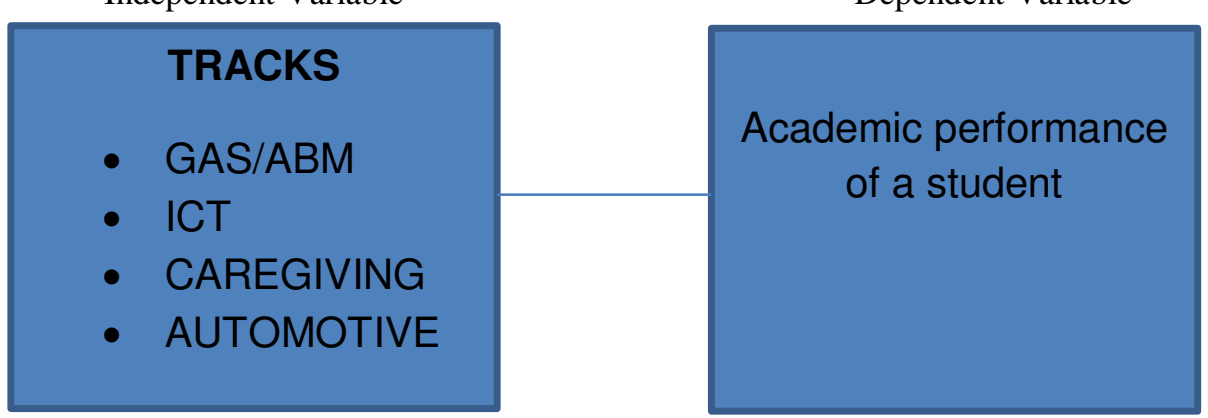

Figure 2. The Paradigm

This figure shows the independent variable and the dependent variable of this study. The independent variable contains the tracks available in the school (GAS/ABM, ICT, CAREGIVING, AUTOMOTIVE) and the dependent variable contains the academic performance of a student.

\subsection{Hypothesis}

The initial solution to the problem of this study is:

There is no significant relationship between sleep satisfaction and the academic performance of Grade 12 students.

\subsection{Statement of the Problem}

This study aimed to show the relationship of sleep satisfaction to the performance of a student in school.

The purpose of the study is to help the readers understand and gain knowledge of what the students are experiencing when they lacked sleep at night.

Specifically, it seeks to answer the following questions:

- What is the mean level of sleep satisfaction of a student?

- What is the mean level of a student's performance in school?

- Is there a significant relationship between sleep satisfaction and the performance of a student in school?

\subsection{Significance of the Study}

The results of the study will be beneficial to the following persons:

- Students. The result of the research will help those students to understand a situation of a student experiencing sleep deprivation.

- Parents. This study will help the parents to educate their children of what to do to prevent lack of sleep at night.

- Teachers. This study will help the teachers to better guide and help the parents in guiding the students to prevent sleep deprivation and to know why some students are sleeping and not participating well in school.

- Future Researchers. This study will make use as a reference of the future researchers about the related topic.

1.6. Scope and Limitation 
This research focused more on the relationship of sleep satisfaction and the student's performance in school for the school year 2021-2022. The Senior High School Students of Talangan Integrated National High School are the respondents of this study.

\subsection{Definition of Terms}

The following are definition of key terms used in this study. They are defined in three ways: defined universally, how it is used in this study, and how it is measured.

Sleep Satisfaction is defined as satisfied someone is with his or her sleep. In this study, sleep satisfaction is used to know the student's performance at school. It was measured by getting the student's sleep activity at night by giving them survey questionnaires.

Academic Performance is defined by student's reporting of past semester CGPA/GPA and their expected GPA for the current semester. In this paper, it is used as a basis to know if the students are having or not having enough sleep at night. It was measured by getting the average grade of the students.

Strand is what a senior high school student has to choose as a bridge for their course in college. In this study, it is used as the respondents. It is measured by including it in the survey questionnaire.

\section{Review of Related Literature}

Sleep is needed for the children's healthy development and to maintain all bodily processes to function properly (Stores 2001).

Adolescents usually try to make up their missed sleeping hours during weekend. According to studies, students who change their sleeping schedule during weekend succeed academically worse than those whose sleeping changes are not significant that's why it is not recommended in terms of academics ( Wolfson \& Carskadon 2003).

(Gibson, Powles and Thabane 116, School of Public Health 27) presented that in recent studies, seventy to eighty three percent of the students do not obtain the optimal level of sleep at night. They stayed up late doing their homework and studying. Also, caffeinated beverages and leisure time activities are some reasons why they stay up late (Gibson, Powles, and Thabane 116).

According to (Rechtshaffen \& Bergmann, 2002), sleep is an essential part of life. It is important for the body to function well and too much deprivation of sleep damages the bodies' functioning system that it can eventually lead to death.

Sleep is needed for the good functioning of the body like learning, cellular repair and memory processing and without it these processes will not function properly ( AlDabal and BaHammam 2011).

In the study of Binks (1999), a person who loses total sleep experienced negative mood, fatigue, sleepiness and drops alertness and performance. Some of them experienced hallucinations and being paranoid. Systematic studies about total sleep loss revealed some temporary intellectual insufficiency but no permanent effects.

(Harvey, Stinson, Whitaker, Moskovitz, \& Virk, 2008; Scott \& Judge, 2006) discoursed that sleep there are two important concepts related to sleep loss; sleep quantity which is the amount of time spent in sleeping and sleep quality which refers to difficulty of falling asleep, staying asleep and the number of awakenings faced at night.

In other countries, studies show that majority of the people are lacking of sleep during workweek and be likely to sleep longer during their free days (Roenneberg et al. 2003).

At night, adolescents must achieve nine to 10 hours of sleep and a sleep average of seven hours ( Wolfson \& Carskadon, 1998). According to ( Randazzo, Muehlbach, Schweitzer, \& Walsh, 1998), a person with too little sleep hours loses focus and concentration and he/she can be inactive and short-tempered in small things.

(Wilson \& Nutt, 2008) stated that people spent around a third of their lives sleeping. Lack of sleep has its negative outcomes: changes in mood, cognitive impairment and disruption to bodily systems ( Durmer \& Dinges, 2005; McEwen, 2006). 
According to Wolfson et al., (1998), students with reduced sleep duration about 25 minutes on 162 average have the possibility to struggle, fail and become sleepy at school.

Sleep deprivation sometimes contributes to accidents. In military operations, some of their failures, accidents, and friendly-fire incidents were caused by lack of sleep of the people. (Belenky et al.1994).

All the above cited readings are mentioned because they are related to the study conducted by the researcher about the relationship of sleep satisfaction and the performance of a student at school.

\section{Research Design and Methodology}

\subsection{Research Design}

This study made use of quantitative method in doing research where according to Matthews \& Ross (2010), this method is mostly used in data gathering that is structured and can be denoted numerically. This paper intent to find out what are the relationship of sleep satisfaction and the academic performance of Grade 12 Students of Talangan INHS.

\subsection{Population and Sampling Technique}

The population for this study is the Grade 12 Learners of Talangan Integrated National High School of the School Year 2021-2022. The researcher uses random sampling technique to select the sample from the population.

The researcher used the Slovin's Formula to compute for the sample he/she needed in the study as shown in the table below.

\begin{tabular}{|l|l|l|l|}
\hline Strand $n=\frac{N}{1+N e^{2}}$ \\
\hline 12-Marvelous(GAS-ABM) & Enrollees & Percentage & Sample Size \\
\hline 12-ICT & 28 & $16.47 \%$ & 20 \\
\hline 12-Caregiving & 31 & $18.24 \%$ & 22 \\
\hline 12-Automotive & 45 & $26.47 \%$ & 31 \\
\hline \multicolumn{1}{|c|}{ TOTAL } & 66 & $38.82 \%$ & 46 \\
\hline
\end{tabular}

\subsection{Data Gathering Procedure}

The flowchart below shows the steps in conducting this research. This also involves asking permission to the adviser of each strand to support the study.

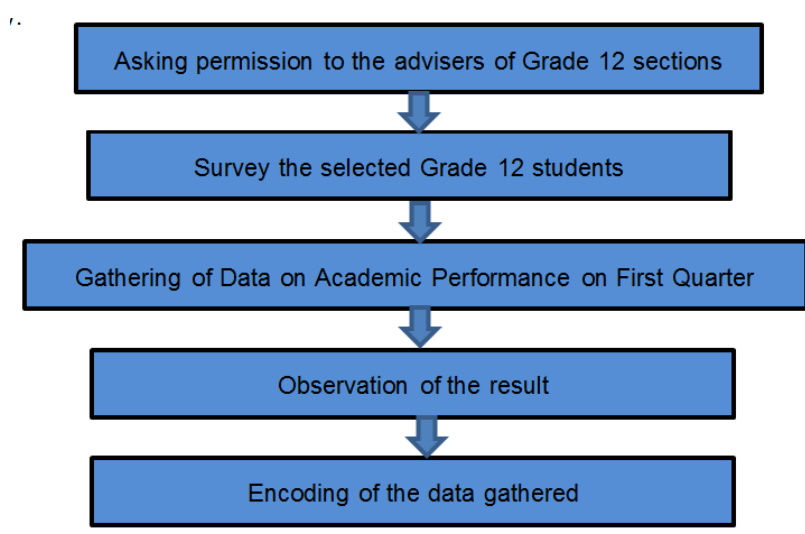


The researcher used survey questionnaires to gather the information needed. It includes 10 questions which are used to give answer to the specific problems encounter in Chapter 1 about the relationship of sleep satisfaction and the academic performance of a student where the students will only check their answers. Data were collected with the use of researcher made and validated survey questionnaire.

Corresponding scale stated as follows:

Rating
5
4
3
2
1

\section{Presentation, Analysis and Interpretation of Data}

This chapter contains the presentation, analysis and interpretation of data gathered in this study.

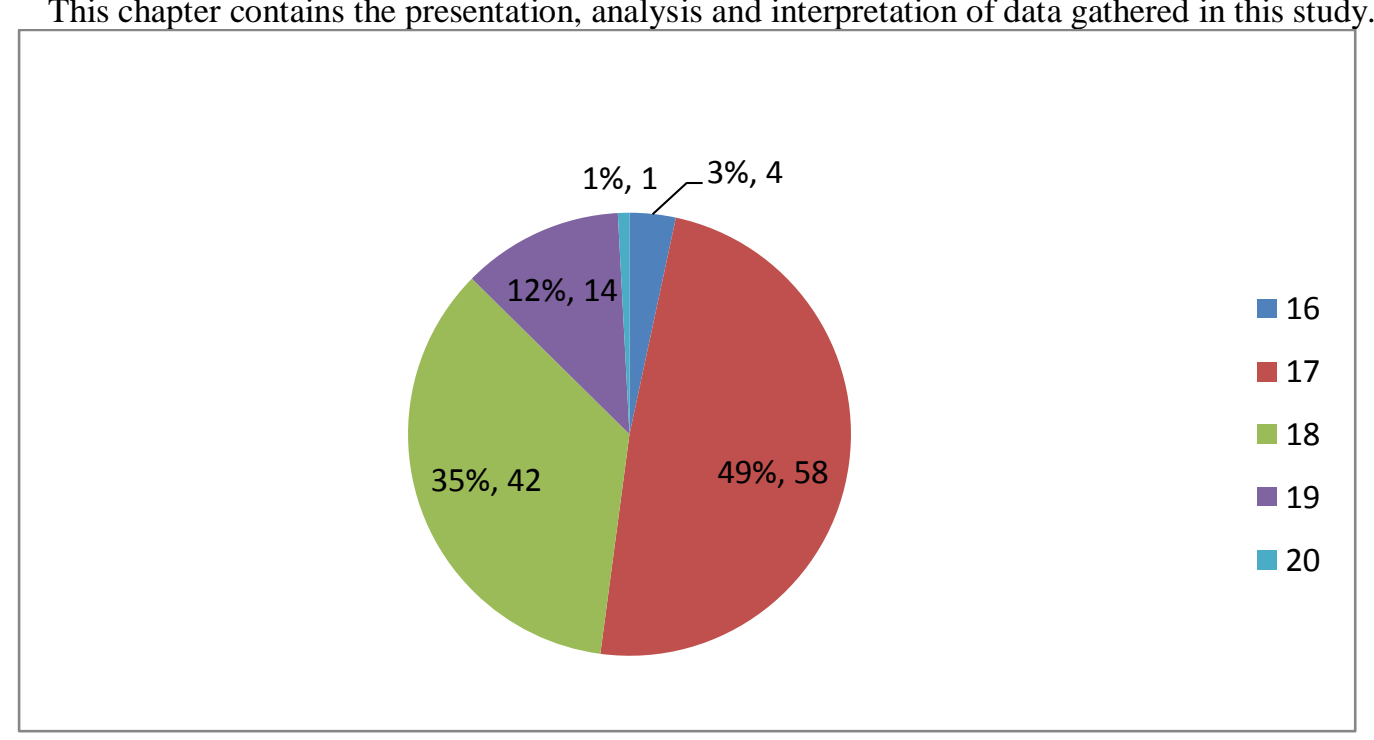

The chart above shows the ages of the students where $3 \%$ of them are 16 years old. $49 \%$ of them are 17 years old while $35 \%$ of the respondents are 18 years old. $12 \%$ of the students are 19 years old and only $1 \%$ is 20 years of age.

This shows that the ages of the students are not a big deal because their performance in school in terms of sleep satisfaction does not depend on their age.

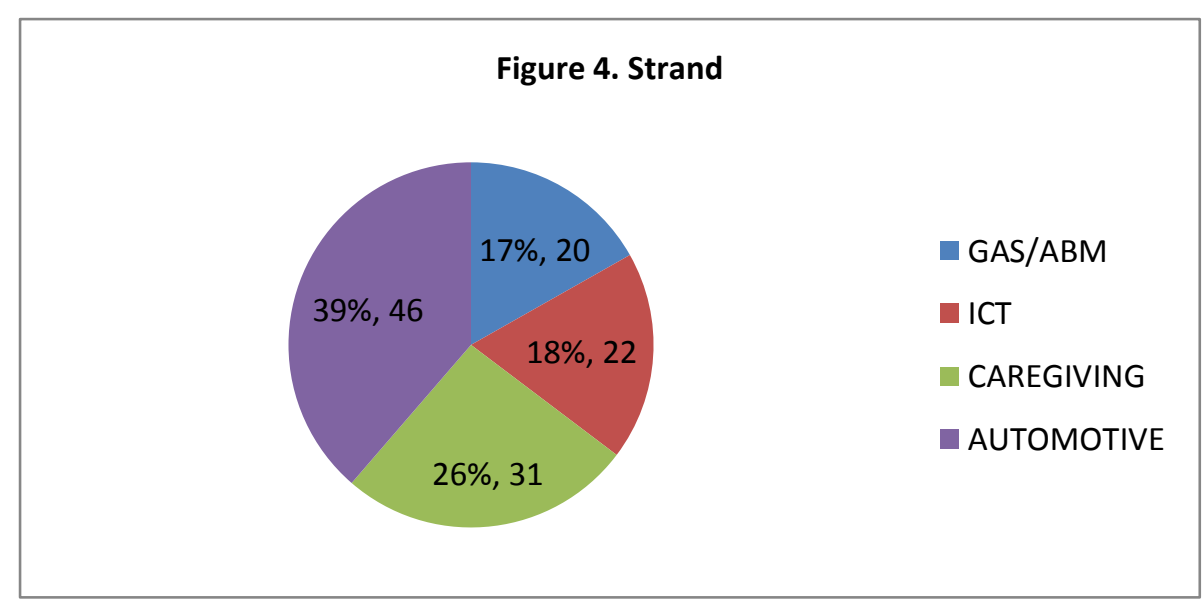


The chart shows the strands of the respondents of this study. $17 \%$ of them belong to GAS/ABM 164 while $18 \%$ are ICT students. $26 \%$ of the respondents are CAREGIVING and $39 \%$ of them belong to AUTOMOTIVE strand.

This illustrates that most of the respondents of this study came from the automotive strand because they have the most number of enrollees compared to the other strands in senior high school.

Table 1.Mean Level of Sleep Satisfaction

\begin{tabular}{|c|c|c|c|}
\hline Indicators & Mean & $\begin{array}{l}\text { Standard } \\
\text { Deviation }\end{array}$ & Interpretation \\
\hline 1. I obtain 8-10 hours of sleep. & 3.66 & 0.88 & $\begin{array}{l}\text { High Level of } \\
\text { Satisfaction }\end{array}$ \\
\hline 2. I go to sleep early. & 3.04 & 1.18 & $\begin{array}{c}\text { Moderate Level } \\
\text { of Satisfaction }\end{array}$ \\
\hline 3. I get enough sleep at night. & 3.19 & 1.12 & $\begin{array}{c}\text { Moderate Level } \\
\text { of Satisfaction }\end{array}$ \\
\hline $\begin{array}{l}\text { 4. I make sure that I will get enough sleep at } \\
\text { night. }\end{array}$ & 3.19 & 1.11 & $\begin{array}{c}\text { Moderate Level } \\
\text { of Satisfaction }\end{array}$ \\
\hline 5. I got up in the middle of the night. & 3.16 & 1.08 & $\begin{array}{c}\text { Moderate Level } \\
\text { of Satisfaction }\end{array}$ \\
\hline 6. I awaken frequently during the night. & 3.03 & 1.03 & $\begin{array}{l}\text { Moderate Level } \\
\text { of Satisfaction }\end{array}$ \\
\hline $\begin{array}{l}\text { 7. It's easy for me to return back to sleep if I } \\
\text { awaken at night. }\end{array}$ & 2.95 & 1.18 & $\begin{array}{l}\text { Moderate Level } \\
\text { of Satisfaction }\end{array}$ \\
\hline $\begin{array}{l}\text { 8. I awaken early in the morning and still } \\
\text { sleepy so I return to sleep. }\end{array}$ & 3.27 & 1.15 & $\begin{array}{l}\text { Moderate Level } \\
\text { of Satisfaction }\end{array}$ \\
\hline 9. I sleep deeply at night. & 3.42 & 1.21 & $\begin{array}{l}\text { Moderate Level } \\
\text { of Satisfaction }\end{array}$ \\
\hline 10. I have good sleep quality at night. & 3.20 & 1.26 & $\begin{array}{l}\text { Moderate Level } \\
\text { of Satisfaction }\end{array}$ \\
\hline AVERAGE & 3.21 & 1.12 & $\begin{array}{c}\text { Moderate Level } \\
\text { of Satisfaction }\end{array}$ \\
\hline
\end{tabular}

Legend:

4.21-5.00

$3.61-4.20$

$2.41-3.60$

$1.81-2.40$

$1.00-1.80$
Very High Level of Satisfaction

High Level of Satisfaction

Moderate Level of Satisfaction

Low Level of Satisfaction

Very Low Level of Satisfaction

The table above shows the sleep satisfaction of the students. Ten questions about it were answered by the respondents. The results of this process were recorded and statistically treated. Questions 1, 2, 3, 4, 5, $6,7,8,9$ and 10 achieved means of 3.66, 3.04, 3.19, 3.19, 3.16, 3.03, 2.95, 3.27, 3.42 and 3.20 respectively and standard deviations of $0.88,1.18,1.12,1.11,1.08,1.03,1.18,1.15,1.21$ and 1.26 respectively.

The indicator that gained the highest mean of 3.66 is the question number one, showing that the respondents are in a high level of satisfaction on obtaining 8-10 hours of sleep, while question number seven obtained the lowest mean of 2.95 , showing that the respondents is on a moderate level of satisfaction in easily 
returning back to sleep if awaken at night. The average mean of the sleep satisfaction is 3.21 and the standard 1650 deviation of 1.12, showing that the respondents obtain moderate level of satisfaction in their sleep.

Table 2.Mean Level of Academic Performance of a Student

\begin{tabular}{|c|c|c|c|}
\hline Indicators & Mean & Standard Deviation & Interpretation \\
\hline 1. I go to school early. & 1.75 & 1.33 & $\begin{array}{c}\text { Very Low Level of } \\
\text { Academic } \\
\text { Performance } \\
\end{array}$ \\
\hline 2. I am always active at school. & 3.46 & 1.02 & $\begin{array}{l}\text { Moderately High } \\
\text { Level of Academic } \\
\text { Performance }\end{array}$ \\
\hline 3. I participate in the discussions. & 3.45 & 1.02 & $\begin{array}{c}\text { Moderately High } \\
\text { Level of Academic } \\
\text { Performance }\end{array}$ \\
\hline $\begin{array}{l}\text { 1. I listen to my teachers during class } \\
\text { discussions. }\end{array}$ & 3.60 & 1.05 & $\begin{array}{c}\text { Moderately High } \\
\text { Level of Academic } \\
\text { Performance }\end{array}$ \\
\hline $\begin{array}{l}\text { 2. I can focus in the discussion during } \\
\text { classes. }\end{array}$ & 3.52 & 1.12 & $\begin{array}{c}\text { Moderately High } \\
\text { Level of Academic } \\
\text { Performance }\end{array}$ \\
\hline 3. I am always present in my class. & 3.79 & 1.16 & $\begin{array}{l}\text { High Level of } \\
\text { Academic } \\
\text { Performance }\end{array}$ \\
\hline 4. I avoid cutting classes. & 3.88 & 1.26 & $\begin{array}{l}\text { High Level of } \\
\text { Academic } \\
\text { Performance }\end{array}$ \\
\hline $\begin{array}{l}\text { 5. I am prepared if there is a quiz on a } \\
\text { subject. }\end{array}$ & 3.50 & 0.98 & $\begin{array}{c}\text { Moderately High } \\
\text { Level of Academic } \\
\text { Performance }\end{array}$ \\
\hline 6. I pass my requirements on time. & 3.56 & 1.10 & $\begin{array}{l}\text { Moderately High } \\
\text { Level of Academic } \\
\text { Performance }\end{array}$ \\
\hline $\begin{array}{l}\text { 7. I comply with all the things needed in } \\
\text { the subjects. }\end{array}$ & 3.71 & 1.09 & $\begin{array}{c}\text { High Level of } \\
\text { Academic } \\
\text { Performance }\end{array}$ \\
\hline AVERAGE & 3.42 & 1.11 & $\begin{array}{c}\text { Moderately High } \\
\text { Level of Academic } \\
\text { Performance }\end{array}$ \\
\hline
\end{tabular}

Legend:

4.21-5.00

3.61-4.20

2.41-3.60

$1.81-2.40$

$1.00-1.80$
Very High Level of Academic Performance

High Level of Academic Performance

Moderately High Level of Academic Performance

Low Academic Level of Performance

Very Low Level of Academic Performance

The table above shows the academic performance of the students. Ten questions about it were answered by the respondents. The results of this process were recorded and statistically treated. Questions 1, $2,3,4,5,6,7,8,9$ and 10 achieved means of $1.75,3.46,3.45,3.60,3.52,3.79,3.88,3.50,3.56$ and 3.71 


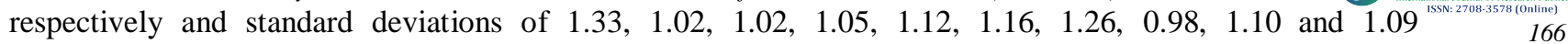
respectively.

The indicator that gained the highest mean of 3.66 is the question number seven, showing that the respondents are in a high level of academic performance on avoiding cutting classes, while question number one obtained the lowest mean of 1.75 , showing that the respondents are on a very low level of academic performance in going to school early. The average mean of the academic performance is 3.42 and the stand20 deviation of 1.11, showing that the respondents obtain moderately high level of academic performance.

\begin{tabular}{|c|c|c|c|c|c|}
\hline Variables & Mean & SD & r-value & p-value & Decision \\
\hline Sleep Satisfaction & 3.21 & 1.12 & 0.82 & 0.00 & $\begin{array}{l}\text { There is a } \\
\text { significant } \\
\text { relationship. }\end{array}$ \\
\hline $\begin{array}{l}\text { Academic } \\
\text { Performance of a } \\
\text { Student }\end{array}$ & 3.42 & 1.11 & & & \\
\hline
\end{tabular}

Table 3. Relationship of sleep satisfaction and academic performance of a student

The table above shows the relationship of the sleep satisfaction and the academic performance of a Grade 12 student in Talangan Integrated National High School. After using Pearson r, it can be seen that the independent and dependent variables' mean are 3.21 and 3.42, respectively, and standard deviation are 1.12 and 1.11 , respectively.

The result of the statistical treatment shows that there is a significant relationship between the two means. The p-value 0.00 , which is lower than the alpha level 0.05 , strengthens the claim. Therefore, the sleep satisfaction of a student significantly affects their academic performance.

The result of this study is the same as the result of the study of Wolfson et al., (1998). The researcher concluded in this study that students with reduced sleep duration about 25 minutes on average have the possibility to struggle, fail and become sleepy at school.

\section{Summary of Findings, Conclusion and Recommendations}

This section of the paper highlights the summary of findings, conclusion, and recommendation of the researcher about the study.

\subsection{Summary of Findings}

The purpose of this study is to know the effects of sleep satisfaction to the academic performance of a student. The following are the things the researcher needs to know in the study:

- What is the mean level of sleep satisfaction of a student?

- What is the mean level of a student's performance in school? 
- Do sleep satisfaction has a significant effect of to the performance of a student in school?

Here are the findings of the research conducted.

- The mean level of sleep satisfaction is 3.21 is the mean(moderate level of satisfaction) and the standard deviation is 1.12

- The mean level of academic performance of a student is 3.42 is the mean (moderately high academic performance) and the standard deviation is 1.11

- The $\mathrm{p}$ value is 0.00

- The $r$ value is 0.82

\subsection{Conclusion}

According to the findings of this study, the sleep satisfaction has a significant relationship to the academic performance of a student. If the student is highly satisfied with his/her sleep, he/she has good performance in school. But, if they are not satisfied with their sleep, they don't perform well in school.

\subsection{Recommendation}

This section of the paper includes the recommendation of the researcher for the Principal, Teachers, Parents, Students and Future Researchers regarding to the findings of this study.

- The principal should conduct a seminar regarding the importance, advantages and disadvantages of sleep deprivation.

- The teachers should minimize the school works so that the students can comply to all home works without deprivation of sleep.

- The parents must check and remind their children to do their home works early and stop doing unnecessary things at night to prevent sleep deprivation.

- The students must perform correct time management to prevent lack of sleep.

\section{Acknowledgment}

I would like to express the deepest appreciation to Dr. Elymar A. Pascual, who continuously motivates us and doesn't get tired of guiding and helping us in doing this paper.

My sincere thanks also go to my parents: Rosie B. Ortillano and Felipe F. Ortillano who support me throughout the making of this research paper especially in financial matters.

Also, I want to thank my fellow classmates (12-Marvelous) who didn't give up on finishing this research paper. For all the advice, help, encouragement and sharing of information for the success of this study.

F. B. O.

\section{References}

Axelrod, J., Goebel, A., \& Jaskiel, R. (2013). Sleep Deprivation may Cause a Student Immense Limitation and Frustration. https://www.chagrinschools.org/Downloads/researcfhSleep\%20deprivation.pdf

Carleton, E. L. (2015). Sleep Well, Work Well: Three Studies. \{Doctoral Thesis, Queen's University\}. https://qspace.library.queensu.ca/bitstream/handle/1974/13849/Carleton_Erica_L_201511_PhD.pdf?sequence=3

Edwards, J. P.(2008). Sleep Habits and Academic Performance.\{Doctoral Thesis ,Auburn University\} https://etd.auburn.edu/bitstream/handle/10415/1174/Edwards_Jennifer_30.pdf?sequence=1

Gabud, R., Manalang, Jr., G., Chua, R. B., Mendoza, E., \& Lozano-Kühne, J. (2015). An assessment of chronotype and social jetlag among Filipinos. International Journal of Philippine Science and Technology, 8(1), 31-40. https://www.philsciletters.net/downloads/008.pdf

Grugle, N.L. (2005). Understanding the Effects of Sleep Deprivation on Executive Function, Complex Task Performance and Situation Awareness. \{Doctoral Thesis, Virginia Polytechnic Institute and State University\}. http://vtechworks.lib.vt.edu/bitstream/handle/10919/26645/NancyGrugleETD2.pdf?sequence=1 
Gunnarsdóttir, K. (2014). Effects of Poor Subjective Sleep Quality on Symptoms of Depression and Anxiety among Adolescents. https://skemman.is/bitstream/1946/19416/1/BSc.Thesis.QualityOfSleep..pdf

Hanish, A.E. (2014). Sleep-related phenotypes: adolescence and PAX6 haploinsufficiency. Iowa Research Online. https://doi.org/ $10.17077 /$ etd.67205vna

Henna, M. (2018). A Study About Student's Sleeping Habits. \{Bachelor's Thesis, Lapland University of Applied Sciences\}. https://www.theseus.fi/bitstream/handle/10024/152508/Thesis-\%20Merenheimo.pdf?sequence=1\&isAllowed=y

Kita, L.A. (2013). Investigating the Relationship between Sleep and Postpartum Depression. \{Doctoral Thesis, Bournemouth University\}.

http://eprints.bournemouth.ac.uk/21200/1/KITA\%2C\%20Lauren\%20Elizabeth_Ph.D._2013\%20with\%20corrections.pdf

Kalogeropoulos, C., Burdayron, R., Laganière, C., Béliveau, M. J., Dubois-Comtois, K., \& Pennestri, M. H. (2021). Investigating the link between sleep and postpartum depression in fathers utilizing subjective and objective sleep measures. Sleep Medicine: X, 3, 100036. https://doi.org/10.1016/j.sleepx.2021.100036

Muruganathan, A., Thirunavuk Karasu, S.M., Ravi Kumar, T., Tamilselvan, N., Saravanan, P., \& Jothi, S. (2017). Sleep Deprivation And its Impact on Doctors Doing Continuous Duties. IOSR Journal of Dental and Medical Sciences, 16(04), $22-25$. https://doi.org/10.9790/0853-1604102225

Snyder, S. L. (2003). The Effects of Sleep Deprivation on Individual Productivity. Marshall Digital Scholar Theses, Dissertations and Capstones, 225. https://mds.marshall.edu/cgi/viewcontent.cgi?article=1225\&amp; context=etd

Vallido, T., Peters, K., O'Brien, L., \& Jackson, D. (2009). Sleep in adolescence: a review of issues for nursing practice. Journal of clinical nursing, 18(13), 1819-1826. https://doi.org/10.1111/j.1365-2702.2009.02812.x 